\title{
Late Prehistoric Oneota Population Movement into the Central Plains
}

\author{
Lauren W. Ritterbush and Brad Logan
}

\begin{abstract}
The White Rock phase is an intrusive Late Prehistoric archaeological complex in the central Plains. It shows clear ties to the Oneota tradition of the upper Midwest. Population movement best explains the presence of this Oneota complex in the Plains. Interpretations of seasonal mobility or migration are evaluated through analysis of White Rock phase assemblages. Evidence for gardening and lithic material use patterns suggest permanent or year-round occupation of the central Plains resulting from the Oneota migration.
\end{abstract}

Keywords: White Rock phase; Oneota; Late Prehistoric; migration; lithic raw materials.

Archaeological studies of central Plains prehistory commonly employ a comparative approach through which cultural continuity is perceived. Anomalous assemblages receive limited attention, resulting in a lack of integration of these data into regional syntheses. An example is what was originally defined as the White Rock aspect (Rusco 1960; Wedel 1986:134-135). Recent reassessment of this archaeological complex has resulted in its redefinition as the White Rock phase (Logan 1995, 1998a). The importance of this phase lies in its association with the Oneota tradition and its temporal placement in the Late Prehistoric period. It has been suggested that the White Rock phase represents the remains of an Oneota population that migrated into the central Plains during the fourteenth century (Logan 1995, 1998a). Given the implications of movement of a foreign population into the region, it is vital to evaluate this interpretation. This evaluation involves identifying the White Rock phase as a site-unit intrusion and the form of population movement it reflects. These analyses build a foundation for future study of the process of migration, Oneota expansion, and the complex cultural dynamics of the central Plains during the Late Prehistoric period.

\section{BACKGROUND}

The White Rock phase includes archaeological assemblages from sites in north-central Kansas and southern Nebraska (Figure 1) (Logan 1995, 1998a). The settlement pattern associated with this phase appears to be one of extensive permanent or semi-permanent villages on upland ridges above White Rock Creek, a tributary of the Republican River, and temporary camps on terraces along other tributaries thereto and along the Solomon River (Rusco 1960; Blakeslee 1999). Artifact assemblages include small triangular arrow points, end scrapers, beveled and unbeveled knives, celts, a variety of bifaces, retouched and utilized flakes, abraders, grinding slabs, anvils, hammerstones, grooved mauls, bone tools (including scapula hoes, awls, flakers, and worked ribs), disk pipes, and pottery. In general, this tool inventory corresponds to those found at Oneota sites outside the central Plains. White Rock ceramics provide clear evidence of ties between the White Rock phase and Oneota tradition.

Despite long recognition and study of Oneota assemblages elsewhere in the upper Midwest, that archaeological manifestation remains poorly defined. This stems in large part from its broad

Lauren W. Ritterbush, Department of Sociology, Anthropology, and Social Work, Kansas State University, Manhattan, Kansas 66506

Brad Logan, Museum of Anthropology, University of Kansas, Lawrence, Kansas 66045

Plains Anthropologist, Vol. 45, No. 173, pp. 257-272, 2000 
temporal and spatial range. Oneota sites date between $\mathrm{AD} 1000$ and the early historic period and are commonly found in the Prairie Peninsula of Iowa, Illinois, Wisconsin, southern Minnesota, and northern Missouri (Boszhardt et al. 1995; Gibbon n.d.; Green 1995; Henning 1998a). Additional remains have been found in areas considered peripheral to this Oneota heartland (such as the central Minnesota woodlands, northeastern Plains, central Plains) (Bozell and Carlson 1999; Gibbon 1995; Henning 1998a). The artifacts most commonly used to identify Oneota sites are ceramics. In general these are shell-tempered, smoothsurfaced globular jars with rounded bases. They may be undecorated or decorated with trailed lines, punctates, or tool impressions. Walnut Decorated Lip ware from White Rock phase sites is clearly comparable to Oneota ceramics (Logan 1995, 1998a; Marshall 1969; Rusco 1960). This similarity can be explained through the process of migration (Logan 1995, 1998a).

Migration is defined "as a permanent or semipermanent change of residence" (Lee 1966:49). Archaeological interpretation of this form of population movement is commonly based on the identification of an intrusive population or site-unit intrusion (Willey et al. 1956; Rouse 1958, 1986; Haury 1958). Rouse (1958:64) suggested that the following five steps must be followed:

in order to demonstrate adequately that migration has taken place: 1) identify the migrating people as an intrusive unit in the region it has penetrated; 2) trace this unit back to its homeland; 3) determine that all occurrences of the unit are contemporaneous; 4) establish the existence of favorable conditions for migration; and 5) demonstrate that some other hypothesis, such as independent invention or diffusion of traits, does not better fit the facts of the situation.

Haury applied a similar approach in his identification of migration at Point of Pines, Arizona.

A migration is the probable, though not the only, explanation in the archaeological record of past people:

1) if there suddenly appears in a cultural continuum a constellation of traits readily identifiable as new, and without local prototypes, and 2) [i]f the products of the immigrant group not only reflect borrowed elements from the host group,

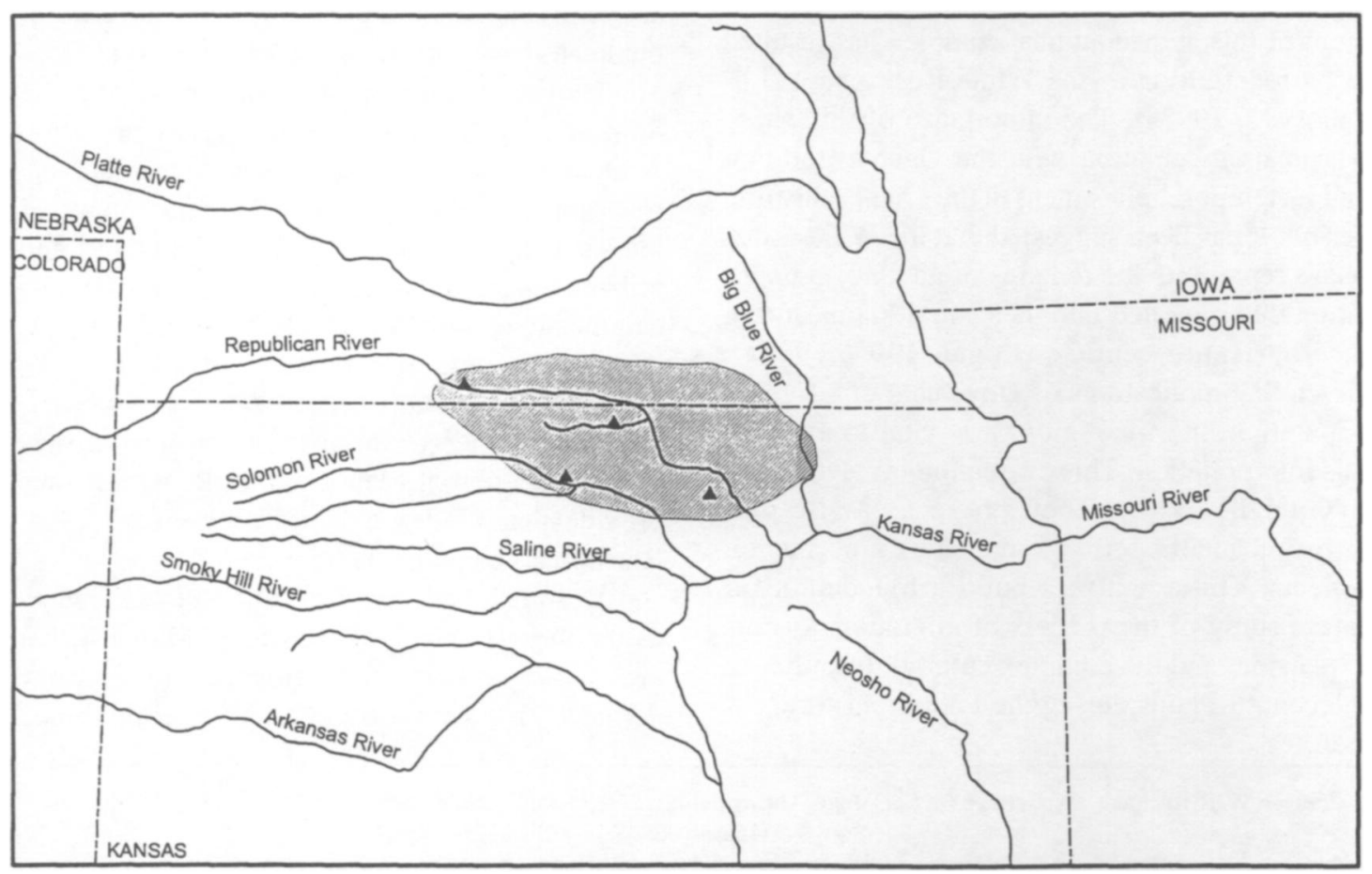

Figure 1. Geographical distribution of White Rock sites in southern Nebraska and north-central Kansas. 
but also, as a lingering effect, preserve unmistakable elements from their own pattern.

The probability that the phenomena outlined above do indeed represent a migration, rather than some other force that induces culture change, is increased:

1) if identification of an area is possible in which this constellation of traits was the normal pattern, and 2) if a rough time equivalency between the "at home" and the displaced expressions of the similar complexes can be established (Haury 1958:1).

The above statements illustrate how Rouse (1958) and Haury (1958) sought to identify prehistoric migrations through the identification of intrusive archaeological units. These units must share at least some defining characteristics with contemporaneous units outside the region. Rouse (1958:64-66) added that evidence for "favorable conditions for migration" must be shown. Although this is a laudable point, identifying favorable conditions or causes for migration is an extremely difficult task for the researcher dealing with prehistoric people. This is due in large part to the many factors (economic, social, ideological) and individual perspectives that affect the complex decision-making process of migration and limits of the archaeological record (Anthony 1990:898-899, 1997). Favorable conditions for migration can be viewed as push and pull factors, as well as possible obstacles perceived by the potential migrants for the area of origin, area of destination, and intervening space (Anthony 1990; Lee 1966).

Rouse's (1958) last step echoed an introductory statement by Haury (1958:1) that "[ $t]$ he archaeologist must, in the course of his analysis, sort out the clues which truly reflect population movement from those which may be due to other mechanisms of cultural transmission and change." A variety of cultural processes (such as diffusion, exchange and short-term population movements such as resource procurement trips or visiting) can produce intrusive or anomalous cultural traits in the archaeological record. As a result, careful evaluation of different lines of archaeological evidence is needed to test the hypothesis of migration, as well as alternative hypotheses.

The identification of past migrations should be part of much broader analyses of the process of migration and its ramifications. Much remains to be considered once an instance of prehistoric migration has been shown to be the most likely explanation for a particular archaeological manifestation. Analysis of this process provides insight into the context of the population movement, the obstacles faced, and effects on the migrating, contact, original, and more distant populations. These studies must draw not only on the particular evidence associated with population movement, but also on general principles of migration (Anthony 1990, 1997; Lee 1966; Lewis 1982).

The goal of this research is to initiate the study of Oneota movement into the central Plains through evaluation of the archaeological evidence for migration. It reviews the White Rock phase as an intrusive archaeological complex with ties to the contemporaneous Oneota tradition (cf. Logan 1995, 1998a; Logan and Banks 1994). Alternative explanations for Oneota traits in the central Plains are considered in light of available data.

\section{WHITE ROCK PHASE AS AN INTRUSIVE UNIT}

The Late Prehistoric period in the central Plains is most commonly identified with the Central Plains tradition. The White Rock phase, however, is also associated with this place and time. Geographically, the White Rock phase and the Central Plains tradition overlap in north-central Kansas and southern Nebraska (Figures 1 and 2). The Smoky Hill and Upper Republican (here including Solomon River) phases of the Central Plains tradition are situated, in part, in the same region as the White Rock phase. Contemporaneity is suggested by radiocarbon dates; however, careful consideration of these dates and their statistical ranges suggests limited overlap (Blakeslee 1994; Logan 1995, 1998a). Despite their spatial and possibly partial temporal coincidence, the White Rock phase is distinctly different from the Central Plains tradition. The formal contrast between these archaeological complexes is evident through a review of them. The most distinctive differences are in certain artifact classes (primarily ceramics, but also general characteristics of the chipped stone assemblage, arrow points, mauls, and pipes) and settlement and subsistence patterns.

Regional ceramic variability exists within the Central Plains tradition; however, the most com- 


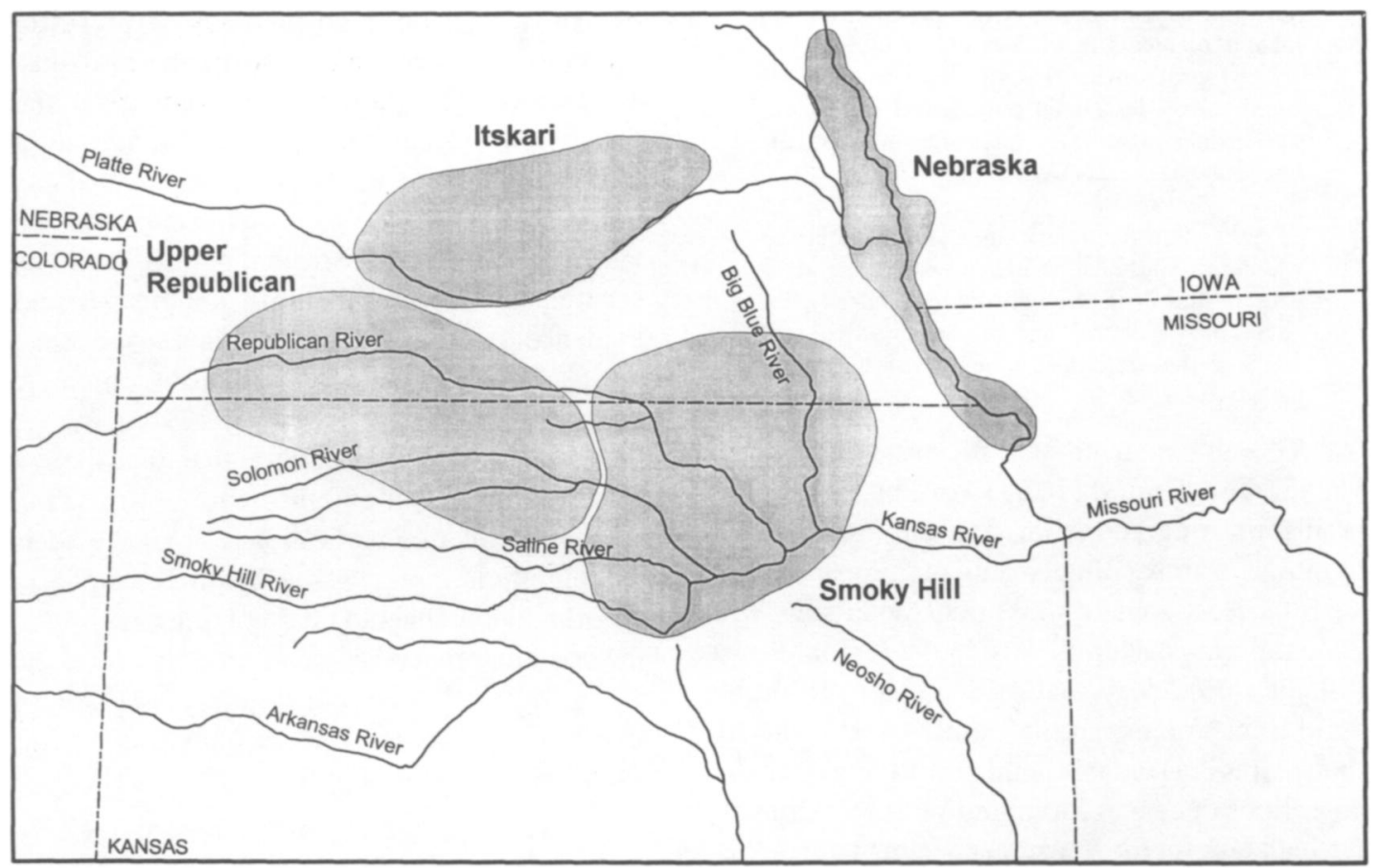

Figure 2. Distribution of the Nebraska, Smoky Hill, Upper Republican (including Solomon River), and Itskari phases of the Central Plains tradition.

mon characteristics of Upper Republican and Smoky Hill pots include a globular to subconoidal shape with rounded shoulders and a cordroughened surface that occasionally was smoothed. Rim form varies from straight to slightly flaring simple and collared varieties. Some pots have undecorated loop or strap handles. Decoration is most often confined to the rim, lip, or both and consists of horizontal incised lines, pinching, and finger or tool impressions. Sherd thickness varies between and on single pots but is more often relatively thick rather than delicately thin. Crushed sherds, grit, or sand was used as temper.

A second type of pottery is found at certain Central Plains tradition sites, especially of the Smoky Hill phase (Beck 1995; Scott 1995). This pottery is smooth-surfaced and shell-tempered. Forms include jars, beakers and water bottles (Scott 1995:49). Jars commonly have short rolled rims and shoulder decorations consisting of sets of incised diagonal lines arranged as alternating triangles.
White Rock ceramics clearly differ from those associated with the Central Plains tradition. The former have a smooth exterior surface that is sometimes simple-stamped or cord-marked. They are thin with shell, sand or grit temper. Jars appear to have been globular with generally high, straight to slightly flaring rims. As implied in the name given by Rusco (1960:30) to this rim type, Walnut Decorated Lip, the most common form of decoration is applied to the top or inside of the lip and consists of tool impressions or incisions (Figure 3a). Other decoration is found on the upper body and handles and includes trailed or incised parallel lines or chevrons sometimes combined with sets of punctates (Figure 3) (Logan 1995, 1998a; Rusco 1960).

Because other industries of the Central Plains tradition and White Rock phase share similar inventories, they are more difficult to differentiate. For example, both include scapula hoes, triangular arrow points, beveled and unbeveled knives, and planoconvex end scrapers. Despite general similarities in tool inventories, direct comparison of assemblages from the two complexes reveals no- 
table differences. The overall impression one gets of White Rock phase chipped stone tools, for instance, is of preference for informal tools or those "with little or no effort expended in their production" (Andrefsky 1994:22). This is readily apparent in the analysis of White Rock arrow points, which are frequently unnotched and formed through minimal retouch of one or more edges of a thin flake (Owada and Ritterbush 1999). This contrasts with the predominant form of Central Plains tradition arrow points that are side notched or side-andbasally notched and were clearly produced through greater effort (e.g., multistage production of bifacial and invasively retouched preforms that were later notched).

Differences between the tool inventories of these two complexes are also apparent in the presence or absence of certain tools. For instance, grooved mauls, common at White Rock sites, are absent at Central Plains tradition sites. Pipes are associated with both complexes but have different forms. A variety of elbow pipes has been found at Central Plains tradition sites. Smoky Hill phase examples include simple carved stone and ceramic forms (Fosha 1994:64; Ritterbush and Logan 1992:114-116,130-131; Johnson 1973:288-289). Upper Republican examples include ceramic and carved stone elbow pipes, as well as pebble pipes (Kivett and Metcalf 1997:122-126). Those found at White Rock sites are markedly different, consisting of disk pipes carved from red pipestone. Such pipes are considered an Oneota horizon style marker (Henning 1998b:11).

Contrasts between the White Rock phase and Central Plains tradition are also seen in settlement and subsistence patterns. Central Plains tradition populations were sedentary, living in substantial permanent or semi-permanent daub or earth structures. These habitations were commonly scattered as single lodges or small clusters of lodges along

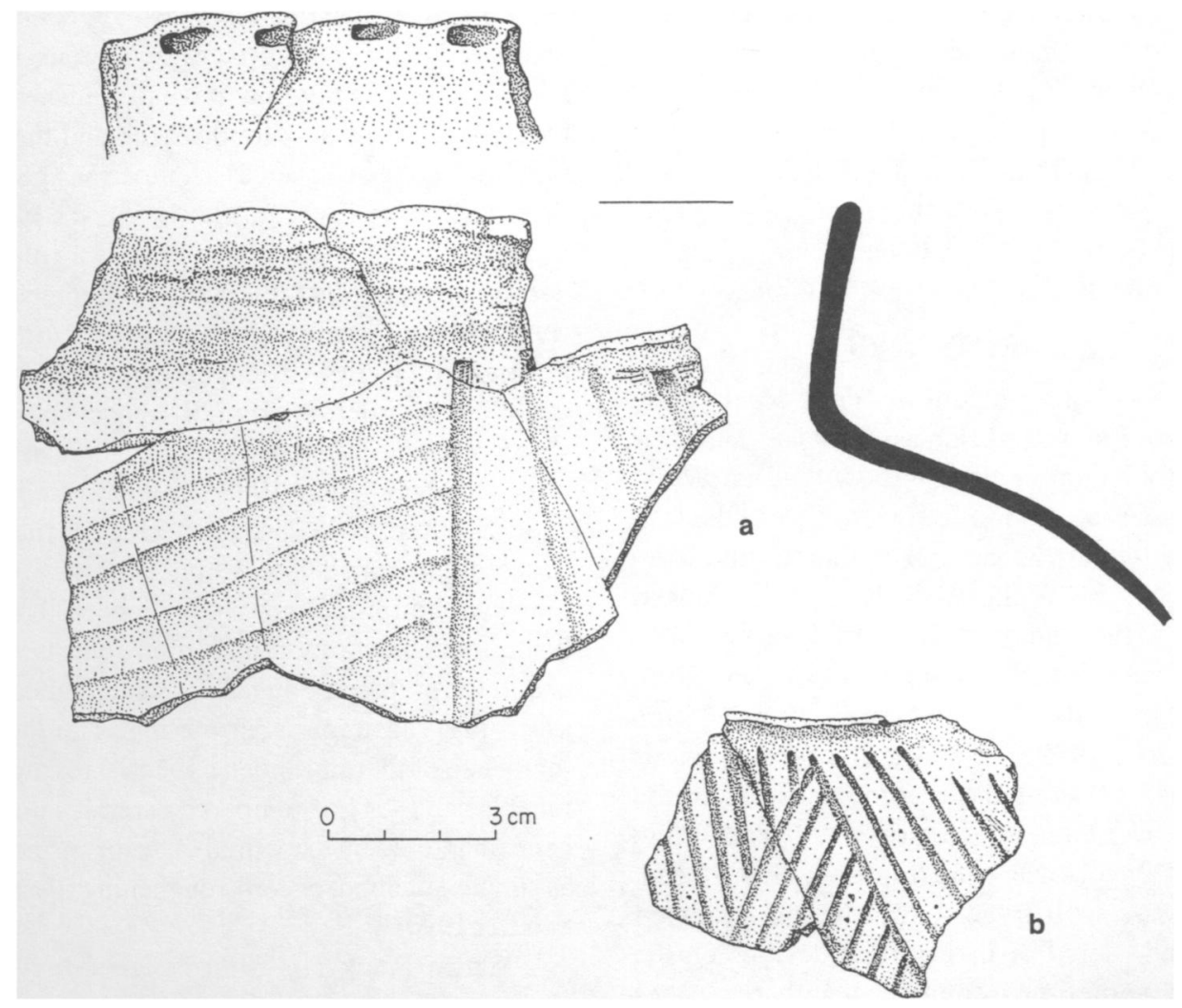

Figure 3. Rim (a) and upper body (b) sherds from the White Rock site (14JW1). 
stream valleys. These settings provided easy access to a wide variety of resources, such as arable land, water, and aquatic and riparian habitats, as well as nearby upland prairies. Distributed in and between the Flint Hills and the High Plains, Smoky Hill and Upper Republican sites were well situated with respect to quality lithic materials, especially Flint Hills (Permian-age) cherts and Niobrara jasper (Smoky Hills silicified chalk). The Central Plains tradition people lived as sedentary hunter-gatherergardeners who depended on a wide variety of readily available local resources.

Focal bison hunting marks the subsistence pattern of the White Rock phase (Logan 1995, 1998a, 1998b). Although evidence for gardening has been found at the larger White Rock sites, garden produce may have served as a supplement to wild resources. Emphasis on bison hunting implies mobility, reflected by unsubstantial house structures and short-term campsites. Vestiges of houses at the White Rock site consist of two areas of postmolds scattered around a hearth (Rusco 1960). These post-supported lodges were probably covered with hides, mats, bark, or other perishable material. White Rock sites include both short-term campsites (e.g., Green Plum and Blue Stone sites) and more permanent settlements (e.g., the Warne and White Rock sites). The latter occupy extensive areas of uplands above White Rock Creek.

\section{ONEOTA TIES}

The contrasting nature of White Rock phase and Central Plains tradition assemblages and their modes of adaptation clearly show that the White Rock phase is a site-unit intrusion. Due to the lack of visible ties to the Central Plains tradition, researchers of the White Rock phase have looked eastward to the Oneota tradition of the upper Midwest for comparable materials (Logan 1995, 1998a; Marshall 1969; Neuman 1963; Rusco 1960; Wedel 1959:612-614). The most obvious similarities between these complexes are in the ceramics. Common characteristics of both White Rock and Oneota wares are thin, smooth-surfaced, globular jars with finger or tool impressions on the lip and trailed or incised line designs on the shoulder, sometimes combined with punctates (Figure 3).

Despite overwhelming ceramic similarities, two attributes, temper and exterior surface treatment, provide a contrast between White Rock and many other Oneota ceramics (e.g., Wedel 1959:612). Early analyses of White Rock assemblages identified a predominance of sand or grit temper (Rusco 1960; Neuman 1963; Marshall 1969). This differs from the characteristic shell temper in Oneota ceramics (Overstreet 1997; Henning 1998a; Gibbon n.d.; Betts 1999). Shell temper also is found in White Rock ceramics, yet was documented in relatively small quantities by Marshall (1969) at the Glen Elder site, by Neuman (1963) at the White Rock, Intermill, and Warne sites, and by Rusco (1960) at the Blue Stone, Glen Elder, and White Rock sites. A significantly higher proportion of shell-tempered ceramics was found in more recently recovered samples from the White Rock site (Wininger and Logan 1995; Logan 1998a). Temper type may be less meaningful as a cultural signature than as a reflection of environmental constraints or adaptive choices. Although mussels are not absent from the central Plains, their quantity may have been limited compared to more eastern prairie regions. Emphasis on bison hunting may have diminished use of freshwater clams as a food source and the potentially related use of shell as a tempering agent. Raw material availability (e.g., clay types) and manufacturing techniques may have played a role in the decision to use sand rather than shell temper in the central Plains. Finally, use characteristics may have influenced selection of tempering materials. A variety of factors, such as strength (impact and thermal shock resistance) and permeability, may have been important here (Betts 1999; Bronitsky and Hamer 1986; Schiffer 1990). Shell temper may not have been necessary, for instance, if pots were not used for intensive boiling. This may have been the case if bison meat was a more common food than corn, and it was prepared using alternative methods, such as drying, roasting, or pit boiling. The increased incidence of thermal shock expected for more permeable sand- or grit-tempered ceramics may have been countered by a textured exterior surface, such as simple-stamping or cord-roughening (Betts 1999; Schiffer 1990).

White Rock rim sherds are consistently smooth while body sherds are occasionally simple-stamped or cord-roughened and often smoothed over. Neither of these traits can be con- 
sidered specifically or exclusively a Central Plains tradition trait. Cord-roughening occurs at many Oneota sites, including Leary, Dixon, and others (Hill and Wedel 1936:35; Fishel 1995:48, 1999:64; Harvey 1979:66; Henning 1995:74-75; Boszhardt 1998:213; Moffat 1998:178-180; Nolan and Conrad 1998:135-139; Jackson 1998:99). One cord-roughened vessel fragment from the White Rock phase Green Plum site illustrates how Walnut Decorated Lip ceramics can include this attribute (Rusco 1960:32-33, 89 Plate 6A). This vessel has a cord-roughened body and a smoothed shoulder. The rim is decorated with parallel diagonal trailed lines forming filled triangles. Parallel diagonal and vertical tool impressions occur on the lip and lip interior respectively. These attributes are comparable to those on Walnut Decorated Lip rim sherds. Other cord-roughened body sherds in White Rock phase assemblages may be from vessels showing similar rim to body variability.

White Rock and Oneota assemblages show considerable overlap not only in ceramics, but in other artifact types. As noted above, White Rock chipped stone tools include a high frequency of informal tools. This compares favorably with the "simple" or "expedient" lithic technology of the Oneota tradition (Finney and Crawford 1999; Gibbon n.d.). Overall the chipped stone, groundstone, and bone industries compare in terms of general inventories and technology. Specific artifact types in White Rock assemblages frequently have equivalents in Oneota assemblages. These include simple unnotched arrow points, grooved mauls, and catlinite disk pipes (Gibbon n.d.; Henning 1998a; Overstreet 1997).
In terms of subsistence, Oneota people were hunters, fishers, gatherers, and farmers who used a wide variety of resources. Although White Rock subsistence appears to differ from this general pattern in that it emphasizes bison hunting, this is not completely unexpected for an Oneota population. Wide variation in Oneota subsistence is evident and likely due to the flexibility of Oneota populations in adapting to their specific ecological settings (Henning 1998a:348). Bison hunting was part of the subsistence activities of many Oneota populations, especially the western Oneota (Henning 1998c; Fishel 1999). Increased emphasis on this activity allowed Oneota migrants to adapt successfully to the central Plains.

Recently obtained radiocarbon dates from the White Rock and Warne sites (Table 1) have led to reevaluation of the previous temporal placement of White Rock materials (Logan and Banks 1994:70-75; Logan 1995:99-101, 1998a). The suggested range of ca. AD 1300-1450 corresponds with a portion of the broader temporal span of the Oneota tradition (ca. AD 900-1700). This range closely overlaps the occupations of several western Oneota sites, particularly Leary and Dixon in extreme southeastern Nebraska and northwestern Iowa respectively (Boszhardt et al. 1995; Fishel 1999:48-50; Logan 1995:99-101, 1998a; Logan and Banks 1994:70-72). The radiocarbon assays demonstrate contemporaneity between the White Rock phase and Oneota tradition.

\section{EXPLAINING ONEOTA IN THE CENTRAL PLAINS}

The White Rock phase is clearly a site-unit intrusion in the central Plains associated with the

Table 1. Radiocarbon dates from White Rock Phase sites'.

\begin{tabular}{llllll}
\hline Site -Fea. No. & Lab No. & C14 Age & A.D. & C13/C12 & Calibrated Age ${ }^{2 .}$ \\
\hline 14JW24 - 1 & Beta-53612 & $660 \pm 80$ & 1290 & N/A & $1283(1302) 1400$ \\
14JW1 - 4 & Beta-65893 & $720 \pm 70$ & 1230 & 24.7 & $1261(1288) 1373$ \\
14JW1 - 4 & Tx-7984 & $510 \pm 40$ & 1440 & -24.6 & $1407(1426) 1439$ \\
14JW1 - 8 & Beta-73924 & $390 \pm 60$ & 1560 & -26.3 & $1443(1478) 1631$ \\
14JW1 - 8 & Tx-8193 & $720 \pm 50$ & 1230 & -24.5 & $1276(1288) 1300$ \\
1. From Logan 1998a. & & & & \\
2. Stuiver and Pearson 1993; one sigma age range and (intercept)
\end{tabular}


Oneota tradition. The intrusive nature of the White Rock phase, its similarity to Oneota manifestations to the east, and its contemporaneity with the latter suggest an actual movement of Oneota people. Other explanations, however, can also be advanced to explain the apparent relationship between the White Rock phase and Oneota tradition. These include diffusion, exchange, and different forms of population movement, such as seasonal or occasional travel, as opposed to permanent migration.

In his analysis of the Glen Elder site (14ML1), a White Rock phase site along the Solomon River in Kansas, Marshall (1969:89-90) presented two possible explanations for Oneota manifestations in the central Plains. The first implies migration ("group that penetrated the Central Plains"), while the second referred to intensive acculturation ("indigenous Central Plains group that has been so strongly influenced by the Oneota culture that the original cultural context is beyond recognition" [Marshall 1969:89]). The latter was not supported by Marshall because of

[t]he restricted spatial distribution and temporal position of the known [White Rock phase] components plus evidence of limited contact with other known cultural complexes (Marshall 1969:89-90).

Additional support is the magnitude of similarities between the White Rock phase and Oneota tradition. Although diffusion of traits commonly occurs as a result of direct or indirect cultural interaction, acculturation to the point of complete or near complete loss of identity is improbable.

Oneota traits have been found in other regions peripheral to the Oneota heartland. Gibbon (1995) suggested that conquest and alliance building, shifting ethnic boundaries and styles, or exchange may explain these occurrences. The former two mechanisms of change are, like acculturation, forms of diffusion that are expected to affect individual traits or sets of traits, rather than entire cultural identities. Likewise, exchange would plausibly result in the appearance of new objects or styles, but would not alter the entire assemblage and settlement and subsistence patterns of the receiving population. Although one or more of these processes may have served as important mechanisms of Oneota expansion into certain regions (potentially the northeastern Plains or central Min- nesota woodlands [Gibbon 1995]), the virtual lack of non-Oneota (e.g., Central Plains tradition) traits in White Rock assemblages makes these explanations unlikely.

The site-unit (rather than trait-unit) intrusion of the White Rock phase provides support for the more plausible explanation of Oneota population movement into the central Plains. Population movement can take various forms. As stated earlier, migration is a form of population movement that involves "a permanent or semipermanent change of residence" (Lee 1966:49). This definition implies a move of relatively large distance and definitiveness (Tilley 1978:50). Less permanent population movements are sometimes referred to simply as a form of mobility, although more precise definitions can further classify population movements (e.g., Tilley 1978:48-57). A form of population movement termed circular migration may explain Oneota presence in the central Plains. Circular migration is frequent movement between two or more places (Gmelch 1980:136; Tilley 1978:5253). This might include seasonal or cyclical movement associated with particular activities, such as procurement of bison products or preferred lithic materials.

Analogies for circular or seasonal migration into the Plains from the east exist from historic times. The eighteenth to early nineteenth century Kansa, a Dhegiha Siouan-speaking group, trekked westward from their permanent villages along the lower Missouri River for annual bison hunts (Unrau 1971:38-39; Norall 1988:61,138). A similar pattern of long-distance bison hunts in the central Plains may have existed for the Late Prehistoric Oneota. In his interpretation of Dixon, an Oneota site in northwestern Iowa, Fishel $(1995: 86-91,1996,1999)$ suggested that its inhabitants participated in communal bison hunts that may have taken them into the central Plains.

Another Oneota group, represented by the White Rock phase (Logan 1995; Logan and Banks 1994), occupied this area of Kansas and Nebraska at this time. While trade between these two groups [Dixon residents and White Rock people] is possible, an alternative hypothesis has been suggested that this area of central Kansas and Nebraska was where the Dixon inhabitants held their hypothesized communal bison hunts (Fishel 1995:91, 1999:129). 
This interpretation of circular migration was based in part on the high percentage of lithic materials from the central Plains represented in certain chipped stone tool categories (e.g., scrapers) in the Dixon site assemblage (Finney and Crawford 1999; Fishel 1995, 1996, 1999). Although Fishel did not state that the White Rock remains were those of Dixon hunters, it might be construed from the above that the White Rock phase represents seasonal or occasional excursions from western Iowa into the central Plains by these people. One possible explanation for the White Rock phase, therefore, is that this archaeological complex represents the remains of activities associated with circular (rather than permanent) migration of Oneota people.

To evaluate this hypothesis, we must determine whether White Rock sites (or the region in which they are distributed) were occupied yearround. Seasonal bison hunts (circular migration) would result in temporary or seasonally occupied sites. The Green Plum and Blue Stone sites of the White Rock phase are interpreted by Rusco (1960) as temporary camps used while hunting bison. Recent reanalysis of the Glen Elder site (14ML1) suggests that this also may have been a temporary camp (Blakeslee 1999). The White Rock (14JW1) and Warne (14JW2/14JW24)

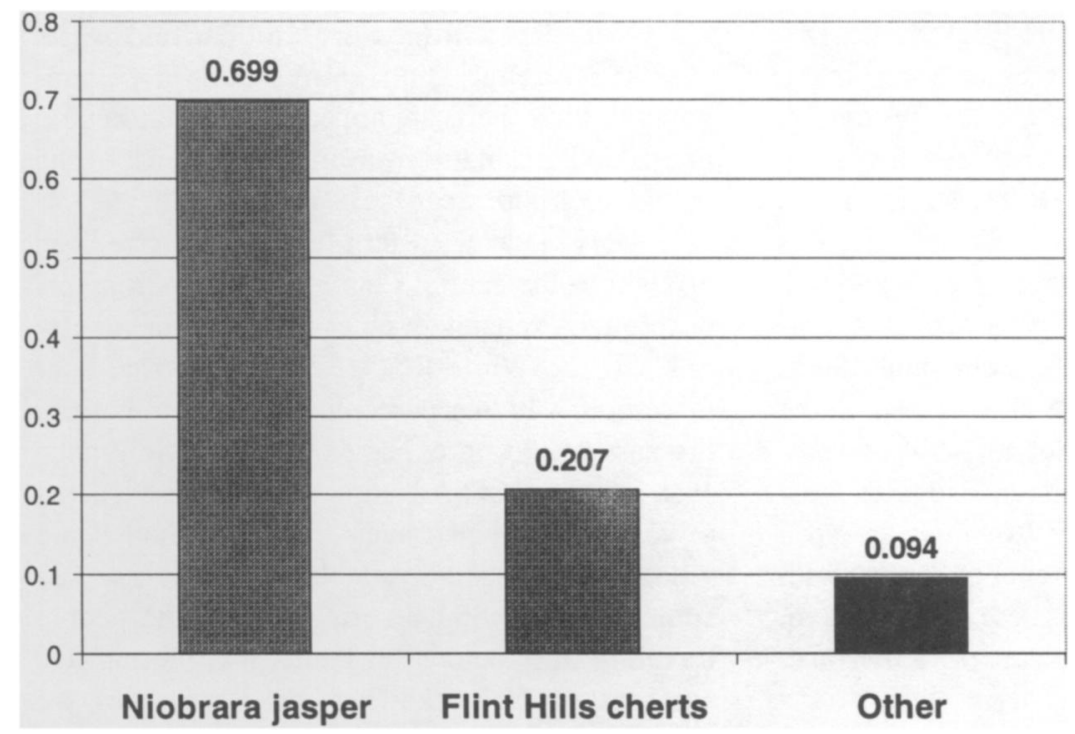

Figure 4. Frequencies of lithic raw materials in the White Rock site (14JW1) assemblage recovered during the 1930s $(n=938)$. sites are interpreted as permanent settlements. Permanence is suggested by their large and varied archaeological assemblages, apparent remains of houses (14JW1), numerous storage and refuse pits, and evidence of gardening. Although the insubstantial and ambiguous nature of the structures and other characteristics of these sites (e.g., their extensive nature) could be explained in terms of either temporary (but repeated) or permanent use, it is difficult to imagine temporary occupation in association with gardening. Evidence for gardening consists of charred corn kernels (Neuman 1963:291-292; Rusco 1960:50) and the frequent occurrence of scapula tools, including hoes and squash knives (Anderson 1994; Logan 1995; Marshall 1969; Neuman 1963; Rusco 1960). An isolated find of two bison scapula hoes on the floodplain of White Rock Creek below the White Rock site may mark the location of gardens used by that site's occupants (Logan and Hedden 1992:34-35). Given the requirements of planting, hoeing, protecting plants from pests, harvesting, and processing (husking, drying, threshing, etc.) garden produce (cf., Wilson 1987), at least semipermanent occupation was necessary.

Permanent (year-round) occupation of the central Plains by Oneota migrants is suggested not only by evidence for gardening, but also by the clear adaptation made by the migrants to the region in terms of lithic resources. Analysis of the chipped stone tools and debris recovered during surface inspection and excavation of the White Rock site (14JW1) in the 1930s reveals dependence on central Plains lithic materials. Of the 938 lithic artifacts in this assemblage, nearly $70 \%$ are of Niobrara jasper (Smoky Hill silicified chalk) (Figure 4). Niobrara jasper, from the Cretaceous 
Niobrara Formation, is exposed in parts of northwestern Kansas and extreme south-central Nebraska (Wright 1985) (Figure 5). Western White Rock phase campsites lie within the source area of this quality lithic material. The abundance of bison bone and worked and unworked pieces of jasper at the Green Plum and Blue Stone sites indicates that these sites were associated with both bison hunting and lithic procurement (Rusco 1960). Jasper used at the more permanent villages in north-central Kansas was probably brought from these or similar camps and nearby quarries.

The second most common lithic material represented in the White Rock site assemblage is Flint Hills chert (Figure 4). Nearly $21 \%$ of the lithics come from outcrops of Permian deposits in the Flint Hills physiographic region, which extends from near the present Nebraska-Kansas border, across eastern Kansas, into Oklahoma (Figure 5). This material also may have been obtained as part of an embedded strategy associated with bison hunting in the Flint Hills.

The predominance of Niobrara jasper may reflect a preference for this lithic material and common western movements of White Rock people. Another indication of possible western orientation is the presence of exotic lithic materials from beyond the central Plains. Chalcedonies (including Flattop and a banded variety) and petrified wood in the White Rock site assemblage likely derive from sources in northeastern Colorado, western Nebraska, eastern Wyoming, or the White River Badlands of southwestern South Dakota (Hoard et al. 1993; Miller 1991; McLean 1999). Other western lithic materials have been identified at the Warne site. A purplish quartzite derives from the Hartville Uplift of eastern Wyoming (Logan 1995:98). Four small flakes of obsidian from Warne have been traced to the Malad region of southeastern Idaho, while two others have been traced to Obsidian Ridge in New Mexico (Hughes 1994, 1995; Logan et al. n.d.). These exotic lithics indicate travel or contact with populations having access to these northwestern, western, and southwestern sources (Ritterbush 1999; Logan et al. n.d.).

The clear preference for central Plains materials, along with connections to more western lithic sources, does not show conclusively that the
White Rock people inhabited the central Plains on a permanent or semi-permanent basis. The heavy dependence on Niobrara jasper and Flint Hills cherts, however, is striking in contrast to the paucity of eastern lithic materials. If Oneota people were using the central Plains only for seasonal activities, we would expect them to have carried tools made of materials derived from their area of origin, generally defined as the Prairie Peninsula and its western boundary with the central Plains.

Lithic materials from the Prairie Peninsula and eastern edge of the central Plains have been identified in the White Rock site assemblage, but in very low frequencies. Less than two percent of the lithics are from eastern sources, including Pennsylvanian and Mississippian deposits. They include Nehawka, Winterset or Stoner, Burlington, and other white unidentified cherts. Nehawka chert is found in northwestern Missouri, southwestern Iowa, southeastern Nebraska, and northeastern Kansas (Blackman 1907; Holen 1991). Winterset and Stoner cherts (which may be indistinguishable from one another) also outcrop in that region (McLean 1998). Burlington, a white fossiliferous chert, is exposed in more eastern deposits in southeastern Iowa, northeastern and central Missouri, and west-central Illinois (McLean 1998; Morrow 1984, 1994). Less than one percent of the White Rock lithics are unidentified white cherts. Although their source cannot be pinpointed, such cherts are not common in the central Plains and are likely from that region east of the White Rock core area (McLean 1999).

Tools made of eastern lithics may have been brought to the central Plains by Oneota migrants or through exchange with eastern Oneota populations. If the White Rock phase reflects circular migration, a higher percentage of materials from the east would be expected. Seasonal migrants, such as hunters of herd animals, would be expected to gear up for their travels at or near their home village using locally available materials. If we assume that the point of origin of Oneota people traveling into the central Plains was present-day southeastern Nebraska (e.g., the Leary site), we would expect fossiliferous cherts from Pennsylvanian deposits to be well represented. These include Argentine, Winterset, Stoner, Westerville, 


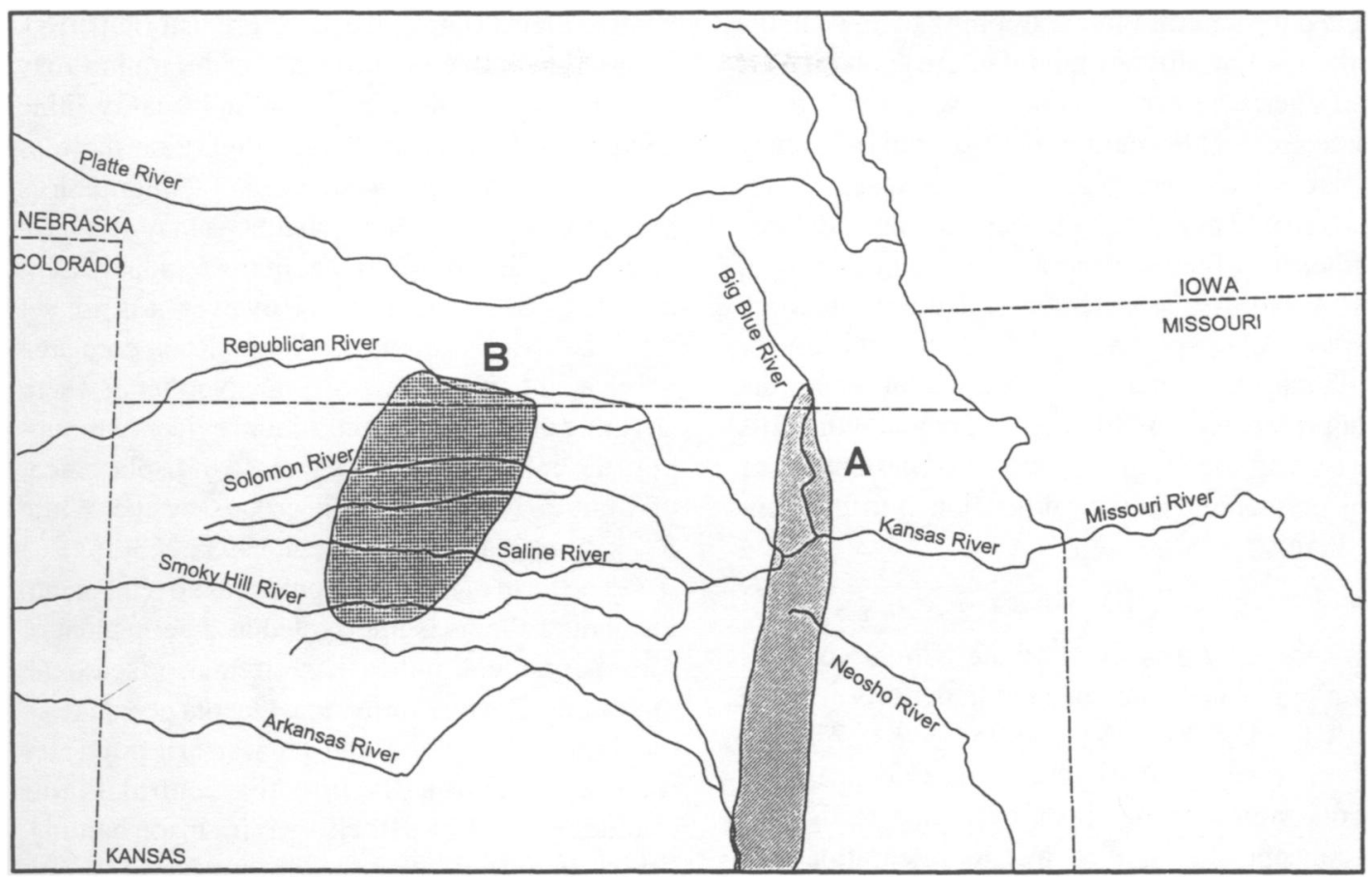

Figure 5. Source areas of (B) Niobrara jasper (Smoky Hill silicified chalk) and (A) Flint Hills cherts. (Modified from Holen [1991:400].)

Plattsmouth, Nehawka, and other cherts (Holen 1983, 1991; McLean 1998; Morrow 1984, 1994; Reid 1980, 1984). Only two artifacts made from Winterset or Stoner chert and possibly five artifacts of Nehawka chert have been identified in the White Rock assemblage.

Travelers originating in northwestern Iowa (e.g., the Dixon site) would be more difficult to identify. Outcrops of lithic materials suitable for chipped stone tool manufacture do not occur in that region. Redeposited materials of relatively poor quality are the only locally available lithics (Anderson 1978; Finney and Crawford 1999; Fishel 1996). As a result, Oneota occupants of this region were dependent on nonlocal materials that were likely obtained through trade and travel. Identification of the Dixon site lithics confirms the use of nonlocal materials by its Oneota occupants (Finney and Crawford 1999). Among these are some of the above-mentioned Pennsylvanian cherts from south of the region, Burlington chert from the southeast, Hixton silicified sandstone and Grand Meadow chert from the northeast, Bijou
Hills silicified sediment and Knife River flint from the northwest, and Flint Hills cherts (Flint Hills Green, Florence D, Florence B, undifferentiated Permian) and Niobrara jasper (Smoky Hill silicified chalk) from the central Plains (Finney and Crawford 1999). Travelers from northwestern Iowa may have carried central Plains lithics back into that region resulting in assemblages that appear in part to be locally derived. These same assemblages, however, would also contain a wide variety of nonlocal lithics comparable to those found at Oneota sites in their homeland. The Dixon site assemblage, for instance, contained Burlington chert in frequencies of $47 \%$, $10 \%$, and $7 \%$ of the arrow points, scrapers, and other tools (bifaces, drills, beveled knives) respectively (Finney and Crawford 1999). This, as well as other lithic materials would be expected at the central Plains campsites of travelers from Dixon or similar western Iowa sites.

There may be other possible explanations for the low percentage of eastern materials in the White Rock site lithic assemblage. One is that the seasonal travelers did not gear up until they had 
reached the central Plains, stopping perhaps in the northern Flint Hills to manufacture tools of Permian cherts before proceeding westward to the source area of Niobrara jasper. Although this may be plausible, it seems unlikely that seasonal migrants would not already be carrying a fairly large number of artifacts made at their point of origin. The very limited representation in the White Rock site assemblage of materials from the Prairie Peninsula and its western border, combined with the clear preference for Niobrara jasper and Flint Hills cherts supports an interpretation of permanent or semi-permanent Oneota migration into the central Plains.

\section{SUMMARY}

Recent reassessment of the White Rock archaeological complex resulted in definition of the White Rock phase (Logan 1995, 1998a). The hypothesis that this phase represents evidence of an Oneota migration has been evaluated in light of the concept of migration and its integration into archaeological research. As noted earlier, Haury (1958:1) stated that migration is probable "if there suddenly appears in a cultural continuum a constellation of traits readily identifiable as new, and without local prototypes." This is certainly true in the central Plains where the "new" White Rock phase appears without any local prototype, or, in other words, appears "as an intrusive unit in the region" (Rouse 1958:64). This intrusive cultural manifestation can be traced, at least generally, to its eastern homeland. The White Rock phase preserves "unmistakable elements" from its pattern of origin (Haury 1958:1), the Oneota tradition. Temporally, the White Rock phase overlaps the Oneota occupations of the not too distant Leary and Dixon sites (Boszhardt et al. 1995; Fishel 1999; Logan 1995:99-101, 1998a; Logan and Banks 1994:70-72). The site-intrusive, rather than trait-intrusive (Willey et al. 1956), nature of the White Rock phase argues for population movement rather than some "other mechanism of cultural transmission and change" (Haury 1958:1; Rouse 1958).

The site-intrusive Oneota remains of the White Rock phase support the interpretation that an Oneota population moved into the heart of the central Plains during the Late Prehistoric period. While "favorable conditions" for migration may have included abundant bison and quality lithic sources in the central Plains, relying on these as pull factors to explain the cause of migration is probably simplistic. Such conditions may also have been set by the abandonment of the region by Central Plains tradition groups. However, it is not yet clear that what became the White Rock core area was vacant upon their arrival. Neither is there anything other than circumstantial evidence to support the inference of an aggressive displacement of Central Plains tradition groups by the White Rock immigrants (cf. Logan 1998a:263-264).

The form of Oneota population movement into the central Plains is interpreted as a permanent or semi-permanent, rather than circular or seasonal, migration. The possibility that Oneota people from the Prairie Peninsula and its western boundary traveled occasionally into the central Plains (including the White Rock area) for bison hunting, lithic procurement, or trade is not ruled out. However, archaeological evidence from the most extensive White Rock sites supports a more plausible interpretation of migration for the White Rock phase. Gardening and dependence on local or nearlocal lithic materials to the near exclusion of eastern lithics provides evidence of permanent or semipermanent occupation of the central Plains.

Understanding Oneota migration in the central Plains is critical to interpreting Late Prehistoric cultural dynamics of the Plains and adjacent Prairie Peninsula. Likewise, it brings us closer to understanding the broader process of Oneota expansion (Benn 1989; Gibbon 1995). Migration theory as developed in other social sciences outlines some of the general principles associated with this cultural process (Lee 1966; Lewis 1982). Integration of these principles into archaeological research provides insight to the context of past migrations, the associated decision-making process, and the implications and ramifications of population movement (Anthony 1990, 1997). It is our hope that continued analysis of Late Prehistoric Oneota and Plains contexts and assemblages will culminate in explication of processes of regional culture change, including migration. 


\section{ACKNOWLEDGMENTS}

Recent research into the White Rock phase has been supported in part by the Grand Island Office of the Bureau of Reclamation and particularly by the administrative efforts of Bob Blasing. Analysis of the 1930s White Rock site assemblage was made possible through collection loans from the Kansas State Historical Society to the University of Kansas Museum of Anthropology and subsequently to the Archaeology Lab of Kansas State University. Isaku Owada and Janice McLean assisted with lithic material identification of this collection with funding provided by a Kansas State University Small Research Grant. Artifacts were illustrated by Sarah Moore, while the maps were prepared with the original assistance of Linda Greatorex and more recently by Bryan Ferguson of the KSU GISSAL Lab. This manuscript has benefited from the comments of reviewers Dale R. Henning and Joseph A. Tiffany, as well as those of $P A$ editor Linea Sundstrom. We gratefully acknowledge the contributions of the aforementioned institutions and individuals.

\section{REFERENCES CITED}

Anderson, Duane C.

1978 Aboriginal Use of Tongue River Silica in Northwest Iowa. Plains Anthropologist 23:149-157.

Anderson, Robert P.

1994 Faunal Analysis of Feature 4, 14JW1. In White Rock Revised: Archaeological Investigation of the White Rock and Warne Sites, Lovewell Reservoir, Jewell County, Kansas, edited by B. Logan, pp. 56-67. University of Kansas, Museum of Anthropology Project Report Series 85, Lawrence.

Andrefsky, William, Jr.

1994 Raw-Material Availability and the Organization of Technology. American Antiquity 59:21-34.

Anthony, David W.

1990 Migration in Archaeology: The Baby and the Bathwater. American Anthropologist 92:895-914.

1997 Prehistoric Migration as Social Process. In Migrations and Invasions in Archaeological Explanation, edited by J. Chapman and H. Hamerow, pp. 21-32. BAR International Series 664 .

Beck, Margaret E.

1995 "Mississippian" Ceramics in the Central Plains Tradition: Petrographic Analysis and Interpretive Models. Unpublished MA thesis, Department of Anthropology, University of Kansas, Lawrence.

Benn, David W.

1989 Hawks, Serpents, and Bird-Men:Emergence of the Oneota Mode of Production. Plains Anthropologist 34: 233-260.

Betts, Colin M.

1999 Shell Temper and the Oneota Tradition. Paper presented at the $64^{\text {th }}$ Annual Meeting of the Society for American Archaeology, Chicago, Illinois.

Blackman, E. E.

1907 Nehawka Flint Quarries. Records of the Past 6:103110.
Blakeslee, Donald J.

1994 Reassessment of Some Radiocarbon Dates from the Central Plains. Plains Anthropologist 39: 203-210.

1999 Glen Elder Revisited:Re-Analysis of the Original Collections. Paper presented at the $57^{\text {th }}$ Annual Plains Anthropological Conference, Sioux Falls, South Dakota.

Boszhardt, Robert F.

1998 Oneota Horizons: A La Crosse Perspective. The Wisconsin Archeologist 79:196-226.

Boszhardt, Robert F., Wendy Holtz, and Jeremy Nienow

1995 A Compilation of Oneota Radiocarbon Dates as of 1995. In Oneota Archaeology:Past, Present, and Future, edited by W. Green, pp. 203-227. Office of the State Archaeologist Report 20,University of Iowa, Iowa City.

Bozell, Rob and Gayle Carlson

1999 Oneota in Nebraska with an Emphasis on the Eighteenth Century Transition to Post-Contact Siouan Tribes. Paper presented at the 57th Annual Plains Anthropological Conference, Sioux Falls, South Dakota.

Bronitsky, Gordon and Robert Hamer

1986 Experiments in Ceramic Technology: The Effects of Various Tempering Materials on Impact and Thermal-Shock Resistance. American Antiquity 51:89101.

Finney, Fred A. with George T. Crawford

1999 Chipped Stone Assemblage. In Bison Hunters of the Western Prairies, edited by R. L. Fishel, pp. 5159. Office of the State Archaeologist Report 21, University of Iowa, Iowa City.

Fishel, Richard L. (Ed.)

1999 Bison Hunters of the Western Prairies: Archaeological Investigations at the Dixon Site (13WD8), Woodbury County, Iowa. Office of the State Archaeologist Report 21, University of Iowa, Iowa City.

Fishel, Richard L.

1995 Excavations at the Dixon Site (13WD8): Correctionville Phase Oneota in Northwest Iowa. Office of the State Archaeologist Contract Completion Report 442, University of Iowa, Iowa City.

1996 Dixon to Leary to White Rock: A Hypothesis for Oneota Fourteenth Century Communal Bison Hunts. Paper presented at the 54th Annual Plains Anthropological Conference, Iowa City.

Fosha, Michael

1994 A Case Study of Inequality Among Smoky Hill Variant Populations. Unpublished MA thesis, Department of Anthropology, University of Kansas, Lawrence.

Gibbon, Guy

1995 Oneota at the Periphery: Trade, Political Power, and Ethnicity in Northern Minnesota and on the Northeastern Plains in the Late Prehistoric Period. In Oneota Archaeology: Past, Present, and Fu- 
ture, edited by W. Green, pp. 175-199. Office of the State Archaeologist Report 20, University of Iowa, Iowa City.

n.d. Oneota. In Encyclopedia of Prehistory, edited by P. Peregrine. Kluwar Academic, New York, in press.

Gmelch, George

1980 Return Migration. Annual Review of Anthropology 9:135-159.

Green, William (Ed.)

1995 Oneota Archaeology: Past, Present, and Future. Office of the State Archaeologist Report 20, University of Iowa, Iowa City.

Harvey, Amy E.

1979 Oneota Culture in Northwestern Iowa. Office of the State Archaeologist Report 12, University of Iowa, Iowa City.

Haury, Emil W.

1958 Evidence at Point of Pines for a Prehistoric Migration from Northern Arizona. In Migrations in New World Culture History, edited by R. H. Thompson, pp. 1-6. University of Arizona Social Science Bulletin 27.

Henning, Dale R.

1995 Oneota Evolution and Interactions: A Perspective from the Wever Terrace, Southeast Iowa. In Oneota Archaeology: Past, Present, and Future, edited by W. Green, pp. 65-88. Office of the State Archaeologist Report 20, University of Iowa, Iowa City.

1998a The Oneota Tradition. In Archaeology on the Great Plains, edited by W. R. Wood, pp. 345-414. University Press of Kansas, Lawrence.

1998b Managing Oneota: A Reiteration and Testing of Contemporary Archeological Taxonomy. The Wisconsin Archeologist 79:9-28.

1998c Oneota: The Western Manifestations. The Wisconsin Archeologist 79:238-247.

Hill, A. T. and Waldo R. Wedel

1936 Excavations at the Leary Indian Village and Burial Site, Richardson County, Nebraska. Nebraska History Magazine 17:2-73.

Hoard, Robert J., John R. Bozell, Steven R. Holen, Michael D. Glascock, Hector Neff and J. Michael Elam

1993 Source Determination of White River Group Silicates from Two Archaeological Sites in the Great Plains. American Antiquity 58:698-710.

Holen, Steven R

1983 Lower Loup Lithic Procurement Strategy at the Gray Site, 25CX1. Unpublished MA thesis, Department of Anthropology, University of Nebraska, Lincoln.

1991 Bison Hunting Territories and Lithic Acquisition among the Pawnee: An Ethnohistoric and Archaeological Study. In Raw Material Economies among Prehistoric Hunter-Gatherers, edited by A. Montet-White and S. Holen, pp. 399-411. Uni- versity of Kansas Publication in Anthropology 19, Lawrence.

Hughes, Richard E.

1994 Sourcing of Obsidian Artifacts from the Warne Locality (14JW8 and 14JW24), Lovewell Reservoir, Kansas. In White Rock Revised: Archaeological Investigation of the White Rock and Warne Sites, Lovewell Reservoir, Jewell County, Kansas, 1993, by B. Logan and W. E. Banks, pp. 80-83. University of Kansas Museum of Anthropology Project Report Series 85, Lawrence.

1995 Sourcing of Two Obsidian Artifacts from the Warne Site (14JW8), Lovewell Reservoir, Kansas. In Phasing in White Rock: Archaeological Investigation of the White Rock and Warne Sites, Lovewell Reservoir, Jewell County, Kansas, 1994. 1995, edited by B. Logan, pp. 120-121. University of Kansas Museum of Anthropology Project Report Series 90, Lawrence.

Jackson, Douglas K.

1998 Settlement on the Southern Frontier: Oneota Occupations in the American Bottom. The Wisconsin Archeologist 79:93-116.

Johnson, Alfred E.

1973 Archaeological Investigations at the Budenbender Site, Tuttle Creek Reservoir, North-Central Kansas, 1957. Plains Anthropologist 18:271-299.

Kivett, Marvin F. and George S. Metcalf

1997 The Prehistoric People of the Medicine Creek Reservoir, Frontier County, Nebraska: An Experiment in Mechanized Archaeology (1946-1948). Plains Anthropologist Memoir 30.

Lee, Everett S.

1966 A Theory of Migration. Demography 3:47-57.

Lewis, G. J.

1982 Human Migration: A Geographical Perspective. Croom Helm, London.

Logan, Brad

1995 Phasing in White Rock: Archaeological Investigation of the White Rock and Warne Sites, Lovewell Reservoir, Jewell County, Kansas, 1994-1995. University of Kansas Museum of Anthropology Project Report Series 90, Lawrence.

1998a Oneota Far West: The White Rock Phase. The Wisconsin Archeologist 79:248-267.

1998b The Fat of the Land: White Rock Phase Bison Hunting and Grease Production. Plains Anthropologist 43:349-366.

Logan, Brad and William E. Banks

1994 White Rock Revised: Archaeological Investigation of the White Rock and Warne Sites, Lovewell Reservoir, Jewell County, Kansas, 1993. University of Kansas Museum of Anthropology Project Report Series 85, Lawrence.

Logan, Brad and John G. Hedden

1992 Archaeological Survey of Lovewell Reservoir, 
Jewell County, Kansas, 1991. University of Kansas Museum of Anthropology Project Report Series 77, Lawrence.

Logan, Brad, Richard E. Hughes, and Dale R. Henning

n.d. Western Oneota Obsidian: Sources and Implications. Plains Anthropologist, in press.

Marshall, James O.

1969 The Glen Elder Focus: The Cultural Affiliations of Archeological Material from the Glen Elder Site, 14ML1. University of Nebraska, Department of Anthropology. Submitted to National Park Service, Midwest Region, U.S. Department of the Interior under the Inter-Agency Archeological Salvage Program, Contract No. 14-10-0232-730 (1963).

McLean, Janice A.

1998 Lithic Raw Material Use at the DB Site. In Prehistoric Settlement of the Lower Missouri Uplands: The View from DB Ridge, Fort Leavenworth, Kansas, edited by B. Logan, pp. 167-197. University of Kansas Museum of Anthropology Project Report Series 98, Lawrence.

1999 Personal communication, University of Kansas Museum of Anthropology, Lawrence.

Miller, James C.

1991 Lithic Resources. In Prehistoric Hunters of the High Plains, 2nd ed, edited by G. C. Frison, pp. 449-476. Academic Press, New York.

Moffat, Charles R.

1998 Oneota in the Central Des Moines Valley. The Wisconsin Archeologist 79:165-195.

Morrow, Toby

1984 Raw Material Descriptions (Appendix A). In Iowa Projectile Points, by Toby Morrow, pp. 99-104. Office of the State Archaeologist, The University of Iowa, Iowa City.

1994 A Key to the Identification of Chipped-Stone Raw Materials Found on Archaeological Sites in Iowa. Journal of the Iowa Archeological Society 41:108129.

Neuman, Robert W.

1963 Archeological Salvage Investigations in the Lovewell Reservoir Area, Kansas. Bureau of American Ethnology Bulletin 185, River Basin Survey Papers 32, Smithsonian Institution, Washington.

Nolan, David J. and Lawrence A. Conrad

1998 Characterizing Lima Lake Oneota. The Wisconsin Archeologist 79:117-146.

Norall, Frank

1988 Bourgmont, Explorer of the Missouri, 1698-1725. University of Nebraska Press, Lincoln.

Overstreet, David F.

1997 Oneota Prehistory and History. The Wisconsin Archeologist 78(1-2):250-296.

Owada, Isaku and Lauren W. Ritterbush

1999 Changes in Late Prehistoric Arrowpoint Technology in North-Central Kansas. Paper presented at the 21 st Annual Flint Hills Archaeological Conference, Lawrence, Kansas.

Reid, Kenneth C.

1980 Upper Pennsylvanian Cherts of the Forest City Basin: Missourian Stage. Plains Anthropologist 25:121-134.

1984 Fusulinacean Sourcing of Late Paleozoic Cherts in the Western Midwest. In Prehistoric Chert Exploitation: Studies from the Midcontinent, edited by B. M. Butler and E. E. May, pp. 253270. Center for Archaeological Investigations Occasional Paper 2.

Ritterbush, Lauren W.

1999 Plains Adaptation Reflected in White Rock Phase Lithic Technology. Paper presented at the 64th Annual Meeting of the Society for American Archaeology, Chicago, Illinois.

Ritterbush, Lauren W. and Brad Logan

1992 Analysis of Three Smoky Hill Variant Sites in NorthCentral Kansas: The Schultz Archaeological Project, Phase II. University of Kansas Museum of Anthropology Project Report Series 78, Lawrence.

Rouse, Irving

1958 The Inference of Migrations from Anthropological Evidence. In Migrations in New World Culture History, edited by R. H. Thompson, pp. 63-68. University of Arizona Bulletin 29, University of Arizona Press, Tucson.

1986 Migrations in Prehistory: Inferring Population Movement from Cultural Remains. Yale University Press, New Haven.

Rusco, Mary Keihl

1960 The White Rock Aspect. The University of Nebraska Laboratory of Anthropology Note Book 4, Lincoln.

Schiffer, Michael B.

1990 The Influence of Surface Treatment on Heating Effectiveness of Ceramic Vessels. Journal of Archaeological Science 17:373-381.

Scott, Frederick William

1995 Tradeware in the Central Plains Tradition: SteedKisker Presence, Influence, and Joining of the Central Plains Tradition. The Kansas Anthropologist $16: 46-68$

Stuiver, Minze and G. W. Pearson

1993 High-Precision Calibration of the Radiocarbon Time Scale, A.D. 1950-500 B.C. and 2500-6000 B.C. Radiocarbon 35:1-23.

Tilley, Charles

1978 Migration in Modern European History. In Human Migration: Patterns and Policies, edited by $\mathrm{W}$. McNeill and R. Adams, pp. 48-74. Indiana University Press, Bloomington.

Unrau, William E.

1971 The Kansa Indians: A History of the Wind People, 1673-1873. University of Oklahoma Press, Norman. 
Wedel, Waldo $R$.

1959 An Introduction to Kansas Archeology. Bureau of American Ethnology Bulletin 174, Smithsonian Institution, Washington.

1986 Central Plains Prehistory: Holocene Environments and Culture Change in the Republican River Basin. University of Nebraska Press, Lincoln.

Willey, Gordon R., Charles C. Di Peso, William A.

Ritchie, Irving Rouse, John $\mathrm{H}$. Rowe, and Donald W.

Lathrap

1956 An Archaeological Classification of Culture Contact Situations. In Seminars in Archaeology: 1955 , edited by $R$. Wauchope. Memoirs of the Society for American Archaeology 11.American Antiquity 22(2)pt.2:1-30.
Wilson, Gilbert L.

1987 Buffalo Bird Woman's Garden. Minnesota Historical Society, St. Paul.

Wininger, Derek C. and Brad Logan

1995 Ceramic Assemblage. In Phasing in White Rock: Archaeological Investigation of the White Rock and Warne Sites, Lovewell Reservoir, Jewell County, Kansas, 1994-1995, edited by B. Logan, pp. 5664. University of Kansas Museum of Anthropology Project Report Series 90, Lawrence.

Wright, Carl $\mathbf{M}$.

1985 The Complex Aspects of the "Smoky Hill Jasper," Now Known as Niobrarite. Journal of the Kansas Anthropological Association 5(3):87-90.

\title{
Request for Materials Plains Anthropological Society Archives
}

The Plains Anthropological Society Archives was developed following discussions at the 1985 Plains Conference in Iowa City. The purpose of the Archives is to assemble and maintain materials related to the Plains Anthropological Society, the Plains Anthropological Conference, and their history. The Archive is permanently located at the University of South Dakota. The Archive is seeking records, photographs, correspondence, and other pertinent documents for curation. Please contact the archivist before sending materials.

\author{
Amy Cooper \\ Special Collections Archivist \\ USD Special Collections \\ I.D. Weeks Library \\ 414 E. Clark Street \\ Vermillion, SD 57069 \\ (605)677-5450 \\ E-mail: alcooper@usd.edu
}

